\title{
Trans-fatty acids and cancer: the evidence reviewed
}

\author{
Abby K. Thompson, Danielle I. Shaw, Anne M. Minihane and Christine M. Williams* \\ Department of Food Biosciences, University of Reading, Reading RG6 6AP, UK
}

\begin{abstract}
The present review comes from the authors of the recent Scientific Advisory Committee on Nutrition (SACN) review Update on Trans Fatty Acids and Health, and focuses on assessing the strength of the evidence for a link between trans-fatty acid (trans-FA) intake and cancer. It evaluates a range of human ecological, case-control and prospective studies with trans-FA exposure assessed using either dietary assessment methods or trans-FA levels in tissues. Relevant animal studies are also presented in order to elucidate potential mechanisms. It concludes that there is weak and inconsistent evidence for a relationship between trans-FA and breast or colorectal cancer. Evidence for an association between trans-FA and prostate cancer is limited, but a recent large case-control study has shown a strong interaction between risk and trans-FA intake for the RNASEL QQ/RQ genotype that is present in about $35 \%$ of the population. This potential association requires further investigation. The single study on non-Hodgkin's lymphoma reported a strong positive association, but only used a single assessment of dietary trans-FA made at the start of the study in 1980, and the significant changes in trans-FA intakes between then and the end of follow-up in 1994 limit the reliability of this observation. There is insufficient evidence to allow any differentiation between the effects of trans-FA from animal or vegetable origin on cancer risk.
\end{abstract}

Trans-fatty acids: Cancer: Breast cancer: Colorectal cancer

\section{Introduction}

The impact of trans-fatty acids (trans-FA) on blood lipids and the subsequent increase in risk of CHD has been extensively described. However, their impact on cancer risk has received less attention. The McGovern report in $1977^{(1)}$ concluded that there was a 'strong correlation' between dietary fatty acids and breast or colon cancer, with a possible mechanism being changes in membrane permeability to carcinogens. SFA were initially targeted as the primary culprit, but Eniq et al. ${ }^{(2)}$ pointed towards a statistical association between vegetable fat intake but not animal fat intake, and suggested that the increase in transFA through the consumption of hydrogenated vegetable fats may be responsible for the observed link between dietary fat and cancer. Since then, there have been a number of studies based on the premise that increased trans-FA consumption may affect risk of cancer, with a focus on cancers of the breast, colon and prostate, with the possibility of trans-FA having potentially adverse hormone-like activity. The current authors wrote the recently published Scientific Advisory Committee on Nutrition (SACN) report Update on Trans Fatty Acids and Health ${ }^{(3)}$, and the present review reports the main findings regarding the evidence for a link between trans-FA consumption and cancer. The report did not include any detailed consideration of the effects of conjugated linoleic acid (CLA), for which there is evidence for beneficial effects in mammary tumours (animal studies) and breast cancer cell lines, possibility due to the antioestrogen-like properties of CLA.

\section{Background}

Trans-fatty acids in the diet

Trans-FA are unsaturated fatty acids with one or more of their double bonds in the 'trans' rather than the common 'cis' configuration. They occur naturally at low levels in dairy products and meats from ruminant animals, but are also produced during the industrial hydrogenation of vegetable oils. The latter process is responsible for many of the semi-solid and solid fats that are widely available as spreads (for example, margarines) and used as a more solid fat source in commercial baked goods (biscuits, pastries) and catering outlets. The predominant trans-FA isomers are vaccenic acid (trans-18:1n-7) and elaidic acid

Abbreviations: CLA, conjugated linoleic acid; EPIC, European Prospective Investigation into Cancer and Nutrition; NHL, non-Hodgkin's lymphoma; RR, relative risk; trans-FA, trans-fatty acid.

* Corresponding author: Professor Christine M. Williams, fax + 44118378 5677, email c.m.williams@reading.ac.uk 
(trans-18: 1n-9), although other MUFA (14:1, 16:1, 18:1) and PUFA (18:2 and 18:3) isomers may also be present at detectable levels in both food products and tissue samples.

The average adult (19-64 years) intake of trans-FA in the UK was reported to be $1.2 \%$ energy in $2000-1^{(4)}$. Recent re-estimation of intake, using dietary data from the National Diet and Nutrition Survey (2000-1) and updated trans-FA composition data, has given an estimated average value of $1.0 \%$ energy for current trans-FA intake in the UK adult population $^{(3)}$. This is significantly lower than in the USA, where the average trans-FA intake was $2.6 \%$ energy in $2003^{(5)}$. In Europe, intakes in 1995 ranged from 0.5 to $2.1 \%$, with the lowest intake levels in the Mediterranean countries and the highest intakes in Iceland ${ }^{(6)}$.

\section{Assessment of trans-fatty acid intake}

The most common methods of estimating trans-FA intake are through FFQ or measuring the levels of trans-FA in tissues. A number of fatty acids are primarily sourced from the diet and cannot be synthesised de novo in the body, including the essential fatty acids linoleic acid $(18: 2 n-6)$ and linolenic acid $(18: 3 n-3)$, the long-chain n-3 PUFA (only limited synthetic capacity) and trans-FA. Levels of these fatty acids in tissue lipid pools are considered to be a more reliable assessment of dietary exposure than dietary questionnaires. This may be particularly important for the relative quantification of trans-FA exposure, as the inability of food composition databases to keep pace with rapidly changing compositions of foods, which include partially hydrogenated vegetable oil sources, may result in significant inaccuracies in estimations of dietary trans-FA intake levels. Trans-FA levels in plasma lipid pools such as cholesteryl esters and phospholipids, in platelets and erythrocytes, and in adipose tissue, may be used as indices of integrated exposure over the previous few days, few months and 1-2 years respectively. However, some disease states result in changes in fatty acid metabolism that are reflected in altered tissue compositions, which could confound retrospective case-control comparisons. In addition, because fatty acid compositional data are expressed as percentage of total fatty acids, any increase or decrease in one fatty acid will result in reciprocal changes in one or more of the other fatty acids present. A further limitation is the inability to directly quantify intake from tissue fatty acid composition. Therefore tissue fatty acid composition data cannot be directly translated into public health recommendations for dietary intake levels associated with reduced risk of disease.

Some prospective studies reported in the present review have undertaken only a single measure of diet at baseline, which may lead to misclassification of habitual trans-FA intake in long-term follow-up, due to changes in subjects' habitual diets over time, as well as changes in food formulations. Given the significant recent changes in fat formulation because of the efforts made by food manufacturers to replace trans-FA in oils and spreads, reliance on historical estimates of intake may lead to large inaccuracies in estimating trans-FA-disease associations.

\section{Presentation of statistical data}

Throughout the present review, the OR and relative risk (RR) stated are those that have been fully adjusted for potential confounding factors. The $P$ for trend values refer to the level of difference between the highest and lowest tertile, quartile or quintile of intake.

When a significant difference in an associated risk was reported, the specific factors that were adjusted for in the model have been shown within the tables. Standard confounding factors for which data have normally been adjusted for include age, BMI and family history. In the case of breast cancer, adjustment for a large number of sitespecific risk factors relating to lifetime hormonal exposure (for example, age at menses, menopause, hormone replacement therapy use, parity, age at first pregnancy, breast-feeding), adiposity, height and alcohol intake are also normally applied.

Dietary trans-FA intakes positively correlate with dietary SFA and total fat intakes. Since total and SFA intakes have been associated with risk of cancers at some sites, it would be expected that epidemiological studies designed to assess the association between dietary trans-FA intake and cancer risk fully adjust for potential confounding by these dietary variables $^{(7,8)}$. Details of adjustments made by each study are given in the tables. The tables show the adjusted RR or OR; however, where adjustment for another dietary variable significantly alters the adjusted RR or OR, this is noted within the text.

\section{Evidence for an association between trans-fatty acids and breast cancer}

\section{Animal studies}

Selenskas et al. ${ }^{\left({ }^{9}\right)}$ investigated the effect of a high-trans-FA diet on a dimethylbenz[a]anthracene-induced rat mammary tumour model. The diets contained $20 \%$ fat by weight, which was either a partially hydrogenated mixture of $50 \%$ soyabean oil and 50\% cottonseed oil (57.5\% 18:1; $22.5 \%$ cis-monoene and $35 \%$ trans-monoene) or a mixture of $58 \%$ olive oil, $40 \%$ cocoa butter and $2 \%$ coconut oil $(54.7 \% 18: 1$; all in cis configuration). Apart from differences in trans-FA, the diets contained similar levels of other fatty acids. Tumour incidences for the trans- and cis-fatty acid diets were 32 and $40 \%$, respectively, with no statistical difference between groups.

Using the same blend of trans- and cis-fatty acids, Erickson et al. ${ }^{(10)}$ examined effects of the diets on the growth and metastasis of implanted mammary tumour cells. The study also considered varying amounts of fat, with diets containing either 5 or $20 \%$ fat by weight. Cells were injected into female BALB/c mice either subcutaneously or intravenously. Mice with subcutaneous implants showed no differences in latency period, tumour growth rate or final tumour size, regardless of fat type or amount. However, in mice receiving the intravenous implants, the liver and spleen from those fed the cis-fatty acid diets contained significantly more viable tumour cells than did those from mice fed the trans-FA diets.

The desaturation of trans-18: $1 n-7$ to form CLA has been observed in rodents, ruminants and human subjects ${ }^{(11)}$, with 
reported conversion rates in rodents of $5-12 \%^{(12)}$ and $19 \%$ in humans ${ }^{(13)}$. Lock et al. ${ }^{(11)}$ observed that when trans$18: 1 n-7$ is converted to CLA it exerts an anticarcinogenic effect against rat mammary tumour initiation and growth. However, the presence of trans-18:1n-7 does not affect cancer development when this conversion is blocked.

\section{Ecological studies}

The methodology and findings for the human studies examining the association between trans-FA and breast cancer are summarised in Table 1.

Bakker et al. ${ }^{(14)}$ investigated the association of breast cancer incidence and trans-FA status across eleven populations. A statistically significant correlation was found between trans-FA and the incidence of breast cancer, with a Pearson correlation coefficient $(r)$ of 0.89 . An increase of $1 \mathrm{~g}$ trans-FA per $100 \mathrm{~g}$ fatty acids in adipose tissue corresponded to a rise in incidence of 19.3 cases of breast cancer per 100000 person-years.

\section{Case-control studies}

London et al. ${ }^{(15)}$ analysed the gluteal adipose tissue of 380 US women with newly diagnosed stage I or II breast cancer and 176 with proliferative benign breast disease. Although trans-FA levels in adipose tissue showed no statistically significant association with the risk of breast cancer, this study used controls subjects who may have had breast abnormalities, which may have biased the findings. Petrek et al. (16) also compared the breast and abdomen tissue fatty acid profiles of women with invasive breast cancer with those of women with a negative diagnosis for breast cancer. No differences in trans-FA concentration were found between the case and control groups for either tissue type.

The European Community Multicentre Study on Antioxidants, Myocardial Infarction, and Breast Cancer (EURAMIC) study ${ }^{(17)}$ compared gluteal adipose tissue trans-FA levels in 698 cases of postmenopausal primary breast cancer and matched controls. There was a strong positive correlation between the adipose tissue level of trans-FA and breast cancer (OR 1.40). The relationship between trans intake and breast cancer appeared to be modified by PUFA intake. OR after stratification by PUFA tertiles were 3.65 and 0.97 for the lowest and highest PUFA tertile, respectively.

Aro et al. ${ }^{(18)}$ reported serum fatty acid levels in 195 cases of breast cancer and 208 population-based controls identified from pre- and postmenopausal Finnish women. The authors reported an inverse association between trans$18: 1 n-7$ and risk of breast cancer with an OR for the lowest $\mathrm{v}$. the highest quintiles of $0 \cdot 2$, but the authors failed to report the statistical significance of this trend. Other trans isomers showed no differences between the case and control populations.

\section{Prospective studies}

Holmes et al. ${ }^{(19)}$ assessed the links between diet and breast cancer in 88795 pre- and postmenopausal women over 14 years in the Nurses' Health Study. There was a small inverse association between trans-FA intake and risk of breast cancer, although this was not statistically significant. Additional analysis of the data, including postmenopausal women who had not reported a diagnosis of benign breast disease, also found no association between trans-FA and breast cancer ${ }^{(20)}$. Similar analysis using 90655 premenopausal women enrolled in the second phase of the Nurses' Health Study again showed no relationship between the disease and dietary trans-FA intake ${ }^{(21)}$. The most recent report on the original cohort brings total follow-up to 20 years, and again reports no association between trans-FA and breast cancer ${ }^{(22)}$.

Pala et al. ${ }^{(23)}$ conducted a prospective study of erythrocyte fatty acids and pre-diagnostic breast cancer (the Hormone and Diet Etiology of Breast Cancer (ORDET) study) in northern Italy. The 4052 postmenopausal participants were followed for an average of 5.5 years, with each case of breast cancer matched with two randomly selected controls. Oleic acid and MUFA were positively associated with the risk of breast cancer, but trans-18:1n-9 (the only trans-FA reported) was not associated with breast cancer risk.

Serum fatty acid concentrations from 197 pre- and postmenopausal cases of breast cancer and matched population-based controls in the New York Women's Health Study were assessed by Saadatian-Elahi et al. ${ }^{(24)}$. The authors found no association between risk of developing breast cancer and serum levels of trans-18:1n-9. No other trans-FA were evaluated in the study.

Voorrips et al. ${ }^{(25)}$ analysed the data from dietary questionnaires of 941 cases of breast cancer and 1598 subcohort controls in the Netherlands Cohort Study. There was a significant positive association between increasing trans-FA intake and risk of breast cancer ( $P$ for trend $=0.01$ ), although the $95 \% \mathrm{CI}$ for the lowest $v$. the highest quintile of dietary intake of trans-FA encompassed 1.0 (RR 1.30; $95 \%$ CI 0.93, 1.80). Further analysis to consider the effect of trans-18:1n-7 showed similar results, with a highly significant trend across the quintiles of intake ( $P$ for trend $=0.006)$. However, the $95 \%$ CI for individual quintiles were consistently non-significant (RR 1.34; $95 \%$ CI $0.98,1.82$ for the lowest $v$. the highest quintile).

Rissanen et al. ${ }^{(26)}$ studied the relationship between serum trans-FA and risk of breast cancer in 127 incident breast cancer cases and 242 matched population-based controls from a prospective study of 8196 women in Finland. Higher serum trans-18:1n-7 levels were associated with an increased risk of breast cancer (OR 3.69), increasing after further adjustment for BMI, serum cholesterol, alcohol intake, education, exercise and parity (OR 4.23). The relationship appeared to be stronger in postmenopausal than in premenopausal women, but the trend failed to reach statistical significance in either group. There was no significant correlation with total MUFA trans-FA.

A subset of women was randomly selected from a large trial (266064 women) of breast self-examination in Shanghai by Shannon et al. ${ }^{(27)}$. Erythrocyte fatty acids were analysed in 322 cases of breast cancer and 367 controls, matched for age and menstrual status. A strong positive association was found between the concentration of trans-18:1n-7 in the erythrocytes and breast cancer (OR 2.21). No other trans-FA were included in the study. 


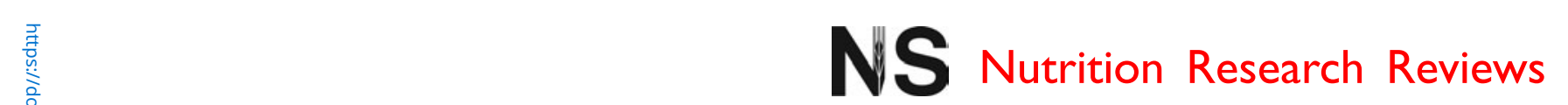

Table 1. Human studies investigating the association of trans-fatty acids (trans-FA) with breast cancer

\begin{tabular}{|c|c|c|c|c|c|c|}
\hline Reference & Subject population & Measure of exposure & $\begin{array}{l}\text { Trans-FA intake } \\
\text { or level (median } \\
\text { of group unless } \\
\text { otherwise specified) }\end{array}$ & $\begin{array}{l}\text { Adjusted RR or } \\
\text { OR with } 95 \% \mathrm{Cl}\end{array}$ & $P$ for trend & Factors adjusted for in analysis \\
\hline \multicolumn{7}{|l|}{ Population study } \\
\hline Bakker et al. ${ }^{(14)}$ & Cancer data & $\%$ trans-FA of total FA & Lowest centre (Granada) & Pearson & & \multirow{5}{*}{$\begin{array}{l}\text { Age, sex, study centre and } \\
\text { laboratory methods }\end{array}$} \\
\hline Europe and Israel & $1982-1987$ & in adipose tissue & $0.13 \mathrm{~g} / 100 \mathrm{~g}$ total FA & correlation & & \\
\hline (ten countries) & FA sample & & Highest centre (Zeist) & coefficient & & \\
\hline & $1991-2$ & & $1.98 \mathrm{~g} / 100 \mathrm{~g}$ total FA & & & \\
\hline & & & & $(0.62,0.97)$ & $\mathrm{N} / \mathrm{A}$ & \\
\hline \multicolumn{7}{|l|}{ Case-control studies } \\
\hline London et al. ${ }^{(15)}$, USA & 556 cases $/ 397$ & $\%$ trans-FA of total FA & Total trans-FA: & & & \multirow{2}{*}{$\begin{array}{l}\text { Risk factors for breast cancer*, } \\
\text { menopause, weight } 5 \text { years } \\
\text { before study, alcohol intake } \\
\text { and prior history of benign } \\
\text { breast disease }\end{array}$} \\
\hline & $\begin{array}{l}\text { hospital-based } \\
\text { controls }\end{array}$ & $\begin{array}{l}\text { in gluteal adipose } \\
\text { tissue }\end{array}$ & $\mathrm{Q} 1=2 \cdot 74, \mathrm{Q} 5=5 \cdot 42$ & $1.2(0.7,1.9)$ & 0.94 & \\
\hline \multirow[t]{2}{*}{ Petrek et al. ${ }^{(16)}$, USA } & 154 cases/125 & $\%$ trans-FA of total FA & Whole population: & 0.528 & 0.13 & \multirow[t]{2}{*}{ Menopausal status and BMI } \\
\hline & $\begin{array}{l}\text { hospital-based } \\
\text { controls }\end{array}$ & $\begin{array}{l}\text { in breast and } \\
\text { abdomen tissue }\end{array}$ & $\begin{array}{l}\text { Cases: mean } 3.80 \text { (SD 1.13) \% } \\
\text { Controls: mean } 4.07 \text { (SD 1.14) \% }\end{array}$ & $(0.257,1 \cdot 08)$ & & \\
\hline \multirow{8}{*}{$\begin{array}{l}\text { Kohlmeier et al. (17), } \\
\text { EURAMIC, Europe } \\
\text { (five countries) }\end{array}$} & 698 cases $/ 698$ & $\%$ trans-FA of total FA & Whole population: & Whole population: & & \multirow{8}{*}{$\begin{array}{l}\text { Standard confounding factorst, } \\
\text { smoking, age, socio-economic } \\
\text { status, study centre, HRT and } \\
\text { adipose PUFA levels }\end{array}$} \\
\hline & postmenopausal & in gluteal adipose & 25 th percentile $0.68 \%$ & $1.40(1.02,1.93)$ & 0.035 & \\
\hline & population-based & tissue & 75th percentile $1.60 \%$ & stratified by \% & & \\
\hline & controls & & & PUFA: & & \\
\hline & & & & $3.65(2 \cdot 17,6.14)$ & & \\
\hline & & & $\%$ PUFA in tissue: & $0.97(0.67,1.40)$ & & \\
\hline & & & $\mathrm{T} 1<12.14$ & & 0.001 & \\
\hline & & & T3 $>15.09$ & & 0.85 & \\
\hline \multirow{2}{*}{$\begin{array}{l}\text { Aro et al. }{ }^{(18)} \\
\quad \text { Finland }\end{array}$} & 195 cases/208 & $\%$ trans-FA of total FA & 18:1n-7: & & & \multirow[b]{2}{*}{$\begin{array}{l}\text { Age (at time of study, menarche, } \\
\text { first full-term pregnancy), area } \\
\text { (rural/urban), oral contraceptive } \\
\text { use, HRT, family history of breast } \\
\text { cancer, history of benign breast } \\
\text { disease, education, alcohol } \\
\text { intake, smoking, physical activity, } \\
\text { waist:hip ratio and BMI }\end{array}$} \\
\hline & $\begin{array}{l}\text { population-based } \\
\text { controls }\end{array}$ & in serum & $\mathrm{Q} 1=0 \cdot 17, \mathrm{Q} 5=0.40$ & $0.2(0.1,0.6)$ & NR & \\
\hline \multicolumn{7}{|l|}{ Prospective studies } \\
\hline \multirow{5}{*}{$\begin{array}{l}\text { Holmes et al. }{ }^{(19)} \text {, } \\
\text { Prospective } \\
\text { cohort (NHS), USA }\end{array}$} & 88795 pre- and & $\%$ energy from & Intake of trans-FA for cohort not given & & NR & \multirow{5}{*}{$\begin{array}{l}\text { Standard confounding factorst, risk } \\
\text { factors for breast cancer, age at } \\
\text { menopause, vitamin A intake, } \\
\text { time period, weight change since } \\
\text { age } 18 \text { years, BMl at age } 18 \\
\text { years, menopausal status, HRT, } \\
\text { history of benign breast disease }\end{array}$} \\
\hline & $\begin{array}{l}\text { postmenopausal women, } \\
2956 \text { events }\end{array}$ & $\begin{array}{l}\text { trans-FA as } \\
\text { assessed by FFO }\end{array}$ & $\begin{array}{l}\text { RR for increase of } 1 \% \text { of energy } \\
\text { from total tans-FA. }\end{array}$ & & & \\
\hline & $1980-94$ & & All women $0.92(0.86,0.98)$ & & & \\
\hline & & & Premenopausal $1.00(0.88,1.11)$ & & & \\
\hline & & & Postmenopausal $0.91(0.84,0.99)$ & & & \\
\hline $\begin{array}{l}\text { Pala et al. }{ }^{(23)} \text {, } \\
\text { Prospective nested } \\
\text { case-control } \\
\text { (ORDET), Italy }\end{array}$ & $\begin{array}{l}71 \text { cases } / 142 \\
\text { postmenopausal } \\
\text { population- } \\
\text { based controls } \\
1987-95\end{array}$ & $\begin{array}{l}\% \text { 18: } 1 n-9 \\
\quad \text { trans-FA } \\
\quad \text { of total FA } \\
\text { in erythrocytes }\end{array}$ & $\mathrm{T} 1<0.25 \%, \mathrm{~T} 3 \geq 0.36 \%$ & $0.7(0.30,1.64)$ & 0.42 & $\begin{array}{l}\text { Age (at time of study, at menarche, } \\
\text { menopause, first birth), BMI, } \\
\text { waist:hip ratio, months of } \\
\text { lactation, parity, and educational } \\
\text { level were considered but none } \\
\text { exerted a major confounding } \\
\text { effect for trans-FA level. } \\
\text { Therefore, the authors chose to } \\
\text { only present only unadjusted OR }\end{array}$ \\
\hline
\end{tabular}




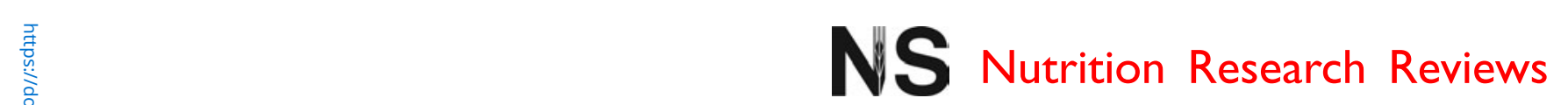

Table 1. Continued

\begin{tabular}{|c|c|c|c|c|c|c|}
\hline Reference & Subject population & Measure of exposure & $\begin{array}{l}\text { Trans-FA intake } \\
\text { or level (median } \\
\text { of group unless } \\
\text { otherwise specified) }\end{array}$ & $\begin{array}{l}\text { Adjusted RR or } \\
\text { OR with } 95 \% \mathrm{Cl}\end{array}$ & $P$ for trend & Factors adjusted for in analysis \\
\hline $\begin{array}{l}\text { Bryne et al. }{ }^{(20)} \text {, } \\
\text { Prospective } \\
\text { cohort (NHS), } \\
\text { USA }\end{array}$ & $\begin{array}{l}31673 \text { women, } \\
\text { postmenopausal, } \\
1071 \text { events, } \\
1980-94\end{array}$ & $\begin{array}{l}\% \text { energy from } \\
\text { trans-FA as } \\
\text { assessed by FFQ }\end{array}$ & $\begin{array}{l}\text { Total trans-FA level of } \\
\text { quintiles not given } \\
\text { Total trans-FA for cohort: } \\
\text { mean } 1.4 \text { (SD 0.5) \% }\end{array}$ & $0.91(0.73,1.13)$ & 0.33 & $\begin{array}{l}\text { Standard confounding factorst, risk } \\
\text { factors for breast cancer }{ }^{\star} \text {, use of } \\
\text { postmenopausal hormones, BMI } \\
\text { at age } 18 \text { years, weight change } \\
\text { since age } 18 \text { years, vitamin A } \\
\text { intake, and other fat subtypes }\end{array}$ \\
\hline $\begin{array}{l}\text { Saadatian-Elahi } \\
\text { et al. }{ }^{(24)} \text {, } \\
\text { Prospective nested } \\
\text { case-control } \\
\text { (New York Women's } \\
\text { Health Study), USA }\end{array}$ & $\begin{array}{l}197 \text { cases } / 197 \\
\text { population- } \\
\text { based controls, } \\
1985-91\end{array}$ & $\begin{array}{l}\% 18: 1 n-9 \text { trans-FA } \\
\quad \text { of total FA in serum }\end{array}$ & $\begin{array}{l}\text { Levels of total trans-FA } \\
\quad \text { (quartiles not given) } \\
\text { Premenopausal: } \\
\text { Cases: mean } 0.4 \text { (SD } 0.2 \text { ) \%; } \\
\text { Controls: mean } 0.5 \text { (SD 0.8) \% } \\
\text { Postmenopausal: } \\
\text { Cases: mean } 0.4 \text { (SD } 0.8 \text { ) \%; } \\
\text { Controls: mean } 0.3 \text { (SD 0.1) \% }\end{array}$ & $\begin{array}{l}\text { All women, } 0.66 \\
(0.33,1.31) \\
\text { Premenopausal: } \\
1.02(0.36,2.88) \\
\\
\text { Postmenopausal: } \\
0.36(0.13,1.03)\end{array}$ & $\begin{array}{l}0.25 \\
0.80 \\
0.33\end{array}$ & $\begin{array}{l}\text { Age at first full-term birth, family } \\
\text { history of breast cancer, history } \\
\text { of benign breast disease and } \\
\text { total cholesterol }\end{array}$ \\
\hline $\begin{array}{l}\text { Voorrips et al. }{ }^{(25)} \text {, } \\
\text { Prospective nested } \\
\text { case-control } \\
\text { (Netherlands } \\
\text { Cohort Study), } \\
\text { The Netherlands }\end{array}$ & $\begin{array}{l}941 \text { cases } / 1598 \\
\text { population- } \\
\text { based controls, } \\
1986-92\end{array}$ & $\begin{array}{l}\text { Intake }(\mathrm{g} / \mathrm{d}) \text { of } \\
\text { trans-FA as } \\
\text { assessed } \\
\text { by FFQ and } \\
\text { diet record }\end{array}$ & $\begin{array}{l}\text { Q1 }=1 \cdot 5, \text { Q5 }=3 \cdot 6 \\
\text { Trans-18: } 1 n-7: \\
\text { Q1 }=0 \cdot 3, \text { Q5 }=1 \cdot 2 \\
\text { Other } 18: 1 \text { trans isomers: } \\
\text { Q1 }=0 \cdot 4, \text { Q5 }=2 \cdot 3\end{array}$ & $\begin{array}{l}1.30(0.93,1.80) \\
1.34(0.98,1.82) \\
0.89(0.65,1.21)\end{array}$ & $\begin{array}{l}0.01 \\
0.006 \\
0.91\end{array}$ & $\begin{array}{l}\text { Standard confounding factorst, risk } \\
\text { factors for breast cancer }{ }^{\star} \text {, age at } \\
\text { menopause, history of benign } \\
\text { breast disease, oral contraceptive } \\
\text { use, BMI, education, smoking } \\
\text { and energy-adjusted fat intake }\end{array}$ \\
\hline $\begin{array}{l}\text { Cho et al. }{ }^{(21)} \\
\text { Prospective cohort } \\
\text { (NHS II), USA }\end{array}$ & $\begin{array}{l}90655 \text { women, } \\
\text { premenopausal } \\
714 \text { events } \\
1991-9\end{array}$ & $\begin{array}{l}\% \text { of energy from } \\
\text { trans-FA as } \\
\text { assessed by FFQ }\end{array}$ & $\mathrm{Q} 1=0 \cdot 9, \mathrm{Q} 5=2 \cdot 3$ & $0.96(0.70,1.31)$ & 0.38 & $\begin{array}{l}\text { Standard confounding factorst, risk } \\
\text { factors for breast cancer }{ }^{*} \text {, history } \\
\text { of benign breast disease, } \\
\text { smoking, oral contraceptives, } \\
\text { menopausal status, energy, } \\
\text { protein intake, other types of fat } \\
\text { and cholesterol }\end{array}$ \\
\hline $\begin{array}{l}\text { Rissanen et al. }{ }^{(26)} \text {, } \\
\text { Prospective } \\
\text { nested case-control } \\
\text { (Mobile Clinic } \\
\text { Health Examin- } \\
\text { ation Survey), } \\
\text { Finland }\end{array}$ & $\begin{array}{l}127 \text { cases } / 242 \\
\text { population- } \\
\text { based controls, } \\
1973-91\end{array}$ & $\begin{array}{l}\% \text { trans-FA of total } \\
\text { FA in serum }\end{array}$ & $\begin{array}{l}\text { Whole population: } \\
\text { Trans-18: } 1 \text { : } \\
\text { T1<0.85, T3<1.15 } \\
\text { Trans-18: } 1 n-7: \\
\text { T1 }<0.32, \text { T3 }>0.41 \\
\text { Postmenopausal: } \\
\text { Trans-18: } 1 \text { : } \\
\text { T1 }<0.32, \text { T3 }>0.41 \\
\text { Trans-18: } 1 n-7: \\
\text { T1 }<0.32, \text { T3 }>0.41\end{array}$ & $\begin{array}{l}1.47(0.65,3.32) \\
3.69(1.35,10.06) \\
7.90(1.46,42.69) \\
2.05(0.54,7.77)\end{array}$ & $\begin{array}{l}0.18 \\
0.17 \\
0.49 \\
0.22\end{array}$ & $\begin{array}{l}\text { Adjusted for standard confounding } \\
\text { factorst, smoking, serum choles } \\
\text { terol, number of pregnancies, } \\
\text { parity, leisure-time exercise and } \\
\text { education; if no significant } \\
\text { difference between adjusted and } \\
\text { unadjusted results the latter were } \\
\text { reported. The results presented } \\
\text { here were unadjusted }\end{array}$ \\
\hline $\begin{array}{l}\text { Kim et al. }{ }^{(22)} \text {, } \\
\text { Prospective cohort } \\
\text { (NHS), USA }\end{array}$ & $\begin{array}{l}80375 \text { women, } \\
\text { postmenopausal, } \\
3537 \text { events, } \\
1980-2000\end{array}$ & $\begin{array}{l}\text { Dietary trans-FA } \\
\text { assessed } \\
\text { by FFQ }\end{array}$ & $\begin{array}{l}\text { Intake of trans-FA for } \\
\text { cohort not given; } \\
\text { RR for increase of } 1 \% \\
\text { energy from } \\
\quad \text { total trans-FA: } \\
\text { All women } \\
\quad 0.99(0.91,1.08) ; \\
\text { Stratified by retrospective } \\
\quad \text { premenopausal intake } \\
1.08(1.01,1.15)\end{array}$ & & $N R$ & $\begin{array}{l}\text { Standard confounding factorst, risk } \\
\text { factors for breast cancer }{ }^{\star} \text {, time } \\
\text { period, weight change since age } \\
18 \text { years, BMI at age } 18 \text { years, } \\
\text { age at menopause, HRT and } \\
\text { benign breast disease }\end{array}$ \\
\hline
\end{tabular}






Table 1. Continued

\begin{tabular}{|c|c|c|c|c|c|c|}
\hline Reference & Subject population & Measure of exposure & $\begin{array}{l}\text { Trans-FA intake } \\
\text { or level (median } \\
\text { of group unless } \\
\text { otherwise specified) }\end{array}$ & $\begin{array}{l}\text { Adjusted RR or } \\
\text { OR with } 95 \% \mathrm{Cl}\end{array}$ & $P$ for trend & Factors adjusted for in analysis \\
\hline $\begin{array}{l}\text { Shannon et al. }{ }^{(27)} \text {, } \\
\text { Prospective } \\
\text { nested case- } \\
\text { control, China }\end{array}$ & $\begin{array}{l}322 \text { cases } / 367 \\
\quad \text { population- } \\
\text { based controls, } \\
1995-2000\end{array}$ & $\begin{array}{l}\% \text { trans-FA of } \\
\text { total FA in } \\
\text { erythrocytes }\end{array}$ & $\begin{array}{l}\text { Trans 18: } 1 n-7: \\
\text { Q1 } \leq 0.85 \\
\quad \text { Q4 } \geq 1.01\end{array}$ & $2 \cdot 21(1 \cdot 25,3 \cdot 88)$ & 0.002 & $\begin{array}{l}\text { Year of interview, age (at time of } \\
\text { study and at first birth), duration } \\
\text { of breast-feeding, time since } \\
\text { last induced abortion and } \\
\text { duration of intra-uterine } \\
\text { device use }\end{array}$ \\
\hline $\begin{array}{l}\text { Chajès et al. }{ }^{(28)} \text {, } \\
\text { Prospective nested } \\
\text { case-control } \\
\text { (E3N-EPIC), } \\
\text { France }\end{array}$ & $\begin{array}{l}363 \text { cases } / 702 \\
\text { population-based } \\
\text { controls, } \\
1995-2002\end{array}$ & $\begin{array}{l}\% \text { trans-FA of } \\
\text { total FA in } \\
\text { serum }\end{array}$ & $\begin{array}{l}\text { Trans-16: } 1 n-7: \\
\text { Cases: mean } \\
0.50 \text { (sD } 0.16) \\
\text { Controls: mean } \\
0.50(\text { sD } 0.16) \\
\text { Trans-16:1n-7 } \\
+18: 1 n-9: \\
\text { Cases: mean } 0.37 \\
\text { (sD } 0.17 \text { ) Controls: } \\
\text { mean } 0.39 \text { (SD } 0.17 \text { ) }\end{array}$ & $\begin{array}{l}2.24(1.30,3.36) \\
1.75(1.08,2.83)\end{array}$ & $\begin{array}{l}0.02 \\
0.018\end{array}$ & $\begin{array}{l}\text { BMI, alcohol consumption, height, } \\
\text { HRT, education level, parity, } \\
\text { family history of breast cancer, } \\
\text { family history of benign breast } \\
\text { disease }\end{array}$ \\
\hline
\end{tabular}

RR, relative risk; FA, fatty acid; N/A, not applicable; Q1, quartile 1 or quintile 1; Q5, quintile 5; EURAMIC, European Community Multicentre Study on Antioxidants, Myocardial Infarction, and Breast Cancer; T1, tertile 1; T3, tertile 3; NR, not reported; HRT, hormone replacement therapy; NHS, Nurses' Health Study; ORDET, Hormone and Diet Etiology of Breast Cancer; NHS II, Nurses' Health Study second phase; EPIC, European Prospective Investigation into Cancer and Nutrition; Q4, quartile 4.

* Risk factors for breast cancer: age at time of study, age at menarche, age at first birth, height, family history of breast cancer and parity.

† Standard confounding factors: energy intake and alcohol consumption. 
The association between serum phospholipid trans-FA and breast cancer risk during 7 years of follow-up was assessed in the French component of the European Prospective Investigation into Cancer and Nutrition (EPIC) study ${ }^{(28)}$ (19934 women). The 363 cases of incident invasive breast cancer were matched to two controls by age, menopausal status at blood collection, whether the subjects were fasting before blood collection, date and collection centre. Increasing levels of serum phospholipid trans$16: 1 n-7$, and combined trans-16:1n-7 and trans $-18: 1 n-9$ were correlated with risk of breast cancer (OR 2.24 and 1.70 , respectively). The levels of cis isomers were unrelated to breast cancer risk.

\section{Summary of evidence for an association between trans-fatty acids and breast cancer}

Prospective cohort, case-control and ecological studies reported between 1994 and 2006 were reviewed. Most of the prospective studies assessed trans-FA exposure by dietary questionnaire; one nested case-control study was based on analysis of erythrocyte fatty acids while another two analysed serum. The five case-control studies used either serum or adipose tissue fatty acids as the measure of exposure. Data from the prospective studies that evaluated dietary trans-FA intake are summarised in Fig. 1.

One of four case-control studies showed a strong positive association between trans levels in tissues and risk of breast cancer. One study reported a negative association between serum vaccenic acid and breast cancer but failed to report values for statistical significance. Three of the ten prospective studies have shown a positive association, with two of these based on measurement of serum or erythrocyte trans-FA levels and one based on dietary transFA assessment. For the latter study, the OR was 1.3 for a highest v. lowest quintile range of $1.5-3.6 \mathrm{~g} / \mathrm{d}$, which is similar to the current range of intakes in the $\mathrm{UK}^{(3)}$. However, there was no significant association found in the three large studies (the Nurses' Health Study, the Hormone and Diet

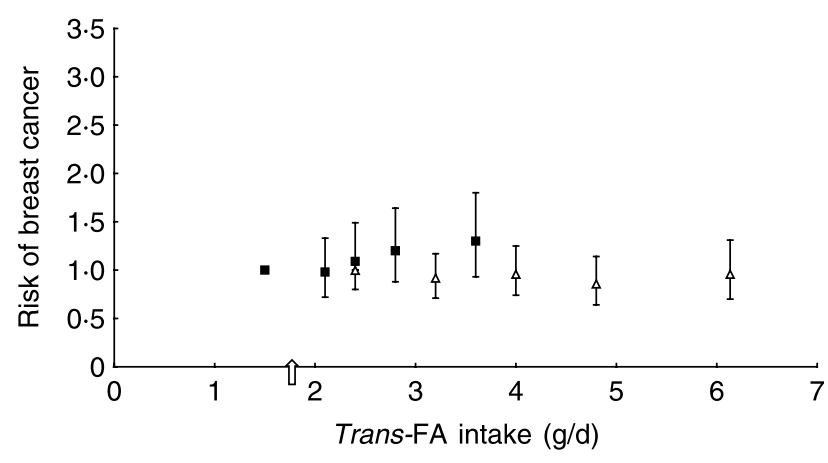

Fig. 1. Risk of breast cancer from prospective epidemiological studies that evaluated dietary intake of trans-fatty acids (trans-FA): Voorips et al. ${ }^{(25)}(\boldsymbol{\square})$ and Cho et al. ${ }^{(21)}(\Delta)$. The current mean transFA intake for women in the UK has recently been estimated to be $1.0 \%$ of total energy or $1.7 \mathrm{~g} / \mathrm{d}^{(3)}(\hat{\imath})$. Risk of breast cancer is plotted as the relative risk (RR), with vertical bars representing the $95 \% \mathrm{Cl}$ for intake ranges above reference $(R R=1)$ in each study. Data from Cho et al. ${ }^{(21)}$ were converted from percentage of total energy to $\mathrm{g} / \mathrm{d}$ based on an energy intake of $1700 \mathrm{kcal} / \mathrm{d}(7113 \mathrm{~kJ} / \mathrm{d})$.
Etiology of Breast Cancer (ORDET) study and the New York Women's Health Study), which have had up to 20 years of follow-up. Overall, the evidence for an association between trans-FA intake and breast cancer is weak. There are limited data from animal studies, and the findings do not provide any evidence to support an effect of trans-FA consumption on mammary tumorigenesis.

\section{Evidence for an association between trans-fatty acids and colorectal cancer}

The methodology and findings for the human studies examining the association between trans-FA and colorectal cancer are summarised in Table 2 .

\section{Animal studies}

Watanabe et al. ${ }^{(29)}$ used the dimethyihydrazine model to examine the effect of trans-FA on colon cancer in Fischer rats. A partially hydrogenated maize oil and olive oil were used at $10 \%$ by weight in the diet, and fed for 15 months. The partially hydrogenated maize oil contained $42 \%$ trans$18: 1$ and $27.2 \%$ cis-18: 1 fatty acids, whereas the olive oil contained $74.1 \%$ cis-18:1. No statistically significant difference in colon tumour incidence was observed, with incidence rates of 35.3 and $31.3 \%$ in animals receiving partially hydrogenated maize oil and olive oil, respectively.

A similar study with a strain of animals especially susceptible to colon cancer (Wistar-Furth-Osaka) was carried out by Sugano et al. ${ }^{(30)}$. High-trans-FA partially hydrogenated maize oil was compared with high-18:1 safflower-seed oil at $5 \%$ of energy. The incidence of dimethylbenz[a]anthracene-induced tumours in the small and large intestines were 63 and $75 \%$, respectively in the animals fed partially hydrogenated maize oil and 65 and $71 \%$, respectively, in the group fed high-18:1 safflowerseed oil.

Hogan \& Shamsuddin ${ }^{(31)}$ fed inbred female F344 rats a diet containing $25 \%$ trans-18:1 fat or $25 \%$ cis-18:1 fat, and injected the animals weekly with azoxymethane to induce large-intestinal carcinomas. Although more animals receiving the diet containing trans-fat developed tumours than those receiving the $c i s$-fat diet, this difference was not statistically significant. Identical numbers of animals from each group developed extracolonic neoplasms.

Reddy et $a l .{ }^{(32)}$ studied the effect of increasing dietary levels of trans-fat on azoxymethane-induced colon carcinogenesis in rats. Three diets were prepared, each containing $23.5 \%$ fat by weight, but with varying amounts of the transfat mix and oleic acid-rich safflower-seed oil (Oleinate), the latter used to balance the amount of $18: 1$ across the diets. The three diets were referred to as low-trans-fat $(5.9 \%$ trans-fat $+11.7 \%$ Oleinate $+5.9 \%$ maize oil), intermediate-trans-fat $(11.7 \%$ trans-fat $+5.9 \%$ Oleinate $+5.9 \%$ maize oil) and high-trans-fat $(17.6 \%$ trans-fat $+5.9 \%$ maize oil). For the low-, intermediate- and high-trans-fat diets, there was no significant differences between diets, with incidences of colon tumours of 63,67 and $57 \%$, respectively, while incidences of small-intestinal tumours were 40,43 and $37 \%$, respectively. 


\begin{tabular}{|c|c|c|c|c|c|c|}
\hline $\begin{array}{l}\text { Reference } \\
\text { Population study }\end{array}$ & Subject population & Measure of exposure & Trans-FA intake or level & $\begin{array}{l}\text { Adjusted } \\
\text { RR or OR with } \\
95 \% \mathrm{Cl}\end{array}$ & $P$ for trend & Factors adjusted for in analysis \\
\hline $\begin{array}{l}\text { Bakker et al. }{ }^{(14)}, \\
\text { Ecological, } \\
\text { Europe and Israel } \\
\text { (ten countries) }\end{array}$ & $\begin{array}{l}\text { Male and female, } \\
\text { Cancer data } \\
\text { 1982-1987, } \\
\text { FA sampling } \\
\text { 1991-2 }\end{array}$ & $\begin{array}{l}\% \text { trans-FA of total FA } \\
\text { in adipose tissue }\end{array}$ & $\begin{array}{l}\text { Lowest centre (Granada) } \\
0.13 \mathrm{~g} / 100 \mathrm{~g} \text { total FA } \\
\text { Highest centre } \\
\text { (Zeist) } 1.98 \mathrm{~g} / 100 \mathrm{~g} \\
\text { total FA }\end{array}$ & $\begin{array}{l}\text { Pearson } \\
\quad \text { correlation } \\
\text { coefficient } \\
r 0.93 \\
(0.74,0.98)\end{array}$ & $\mathrm{N} / \mathrm{A}$ & $\begin{array}{l}\text { Age, sex, study centre and } \\
\text { laboratory methods }\end{array}$ \\
\hline \multicolumn{7}{|l|}{ Case-control studies } \\
\hline $\begin{array}{l}\text { McKelvey et al. }{ }^{(33)} \text {, } \\
\text { USA }\end{array}$ & $\begin{array}{l}516 \text { cases } / 551 \\
\text { controls, male } \\
\text { and female }\end{array}$ & $\begin{array}{l}\mathrm{g} / \mathrm{d} \text { trans-FA intake as } \\
\text { assessed by FFQ }\end{array}$ & Group $1<2$, group $4>6$ & $1.6(0 \cdot 82,3 \cdot 2)$ & Not reported & $\begin{array}{l}\text { Additional confounding factors } \\
\text { age, sex, BMI, red meat } \\
\text { consumption, vegetable } \\
\text { consumption and use of NSAID }\end{array}$ \\
\hline \multirow[t]{6}{*}{$\begin{array}{l}\text { Slattery et al. }{ }^{(34)} \\
\text { case-control, } \\
\text { USA }\end{array}$} & $\begin{array}{l}1993 \text { cases } / 2410 \\
\text { controls, male } \\
\text { and female }\end{array}$ & $\begin{array}{l}\text { Trans-FA g/1000 kcal } \\
\text { energy intake as } \\
\text { assessed by FFQ }\end{array}$ & $\begin{array}{l}\text { Men: } \\
\text { Q1 } 1.69, \text { Q5 }>3.34 \\
\text { Women: }\end{array}$ & $1 \cdot 2(0 \cdot 9,1 \cdot 7)$ & 0.34 & $\begin{array}{l}\text { Age at diagnosis, body size, } \\
\text { physical activity, aspirin } \\
\text { and/or NSAID use, energy }\end{array}$ \\
\hline & & & $\begin{array}{l}\text { Q1 } \leq 1.53, \mathrm{Q} 5>2.99 \\
\text { Women and HRT: }\end{array}$ & $1.5(1 \cdot 1,2 \cdot 0)$ & 0.04 & intake, and dietary $\mathrm{Ca}$ \\
\hline & & & $\mathrm{Q} 1+\mathrm{HRT}$ & 1.00 & $P$ for & \\
\hline & & & $\mathrm{Q} 5+\mathrm{HRT}$ & $0.9(0.6,1.5)$ & interaction & \\
\hline & & & Q1 no HRT & $0.8(0.6,1 \cdot 3)$ & 0.06 & \\
\hline & & & Q5 no HRT & $1.6(1.1,2.5)$ & & \\
\hline $\begin{array}{l}\text { Nkondjock et al. }{ }^{(35)} \text {, } \\
\text { Canada }\end{array}$ & $\begin{array}{l}402 \text { cases } / 668 \\
\text { population-based } \\
\text { controls, male and } \\
\text { female }\end{array}$ & $\begin{array}{l}\% \text { of energy from trans-FA } \\
\text { as assessed by FFQ }\end{array}$ & $\begin{array}{l}\text { Q1 }<0.32 \\
\text { Q4 }>1.60\end{array}$ & $0.83(0.58,1.19)$ & 0.309 & $\begin{array}{l}\text { Standard confounding factorst, } \\
\text { marital status and physical } \\
\text { activity. Total energy, HRT, fibre, } \\
\text { vitamin C and E intakes were } \\
\text { not significantly different between } \\
\text { cases and controls, and were } \\
\text { not included }\end{array}$ \\
\hline \multirow[t]{2}{*}{$\begin{array}{l}\text { Theodoratou et al. }{ }^{(36)} \text {, } \\
\text { Scotland (UK) }\end{array}$} & $\begin{array}{l}1455 \text { cases } / 1455 \\
\text { population-based } \\
\text { controls, male and } \\
\text { female }\end{array}$ & $\begin{array}{l}\mathrm{g} / \mathrm{d} \text { trans-FA intake as } \\
\text { assessed by FFQ }\end{array}$ & $\begin{array}{l}\text { Q1 }<2.88 \text { Q4 }>4.24 \\
\text { Trans-MUFA: }\end{array}$ & $1.15(0.85,1.55)$ & 0.548 & $\begin{array}{l}\text { Standard confounding factorst, } \\
\text { additional confounding factors } \\
\text { use of NSAID, fibre intake and } \\
\text { total FA. }\end{array}$ \\
\hline & & & $\mathrm{Q} 1<2 \cdot 21, \mathrm{Q} 4>3.24$ & $1.30(0.97,1.75)$ & 0.251 & Fully adjusted for all factors \\
\hline \multirow{5}{*}{$\begin{array}{l}\text { Prospective study } \\
\text { Lin et al. }{ }^{\left({ }^{7}\right)} \text {, } \\
\text { Prospective } \\
\text { cohort (Women's } \\
\text { Health Study) USA }\end{array}$} & & & & & & \\
\hline & $\begin{array}{l}37547 \text { women, } \\
202 \text { events, } \\
1993-2003\end{array}$ & $\begin{array}{l}\% \text { of energy from trans-FA } \\
\text { as assessed by FFQ }\end{array}$ & $\mathrm{Q} 1=0.6, \mathrm{Q} 5=1 \cdot 9$ & $1.30(0.89,2.05)$ & $0 \cdot 18$ & $\begin{array}{l}\text { Standard confounding factorst, } \\
\text { additional confounding factors } \\
\text { random treatment assignment, } \\
\text { history of colorectal polyps } \\
\text { and HRT }\end{array}$ \\
\hline & & & & $1.59(0.94,2.70)$ & 0.06 & $\begin{array}{l}\text { Additional adjustment for other } \\
\text { types of fat and cholesterol }\end{array}$ \\
\hline & & & $\begin{array}{l}\text { Trans-18: } 1, n-9: \\
\text { Q1 }=0.5, \text { Q5 }=1.7 \\
\text { Trans-18:2: } \\
\text { Q1 }=0.03, Q 5=0.09\end{array}$ & $1.94(0.92,2.58)$ & 0.08 & $\begin{array}{l}\text { Isomer analysis included } \\
\text { adjustment for types of } \\
\text { fat and cholesterol }\end{array}$ \\
\hline & & & & $1.58(0.94,2.67)$ & 0.09 & \\
\hline
\end{tabular}

RR, relative risk; FA, fatty acid; NSAID, non-steroidal anti-inflammatory drugs; Q1, quartile 1 or quintile 1; Q5, quintile 5; Q4, quartile 4; HRT, hormone replacement therapy. *Additional confounding factors: smoking, physical activity, energy intake and alcohol intake.

† Standard confounding factors: age, BMI and family history of colorectal cancer. 


\section{Ecological studies}

An ecological investigation of the association between colon cancer and trans-FA status found a statistically significant correlation between colon cancer and the level of

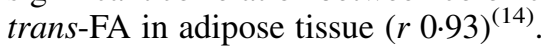

\section{Case-control studies}

The association between colorectal adenomatous polyps and the consumption of foods containing partially hydrogenated oils was examined by McKelvey et al. ${ }^{(33)}$. Dietary intake was obtained from a self-administered FFQ. While there was evidence of a positive association between total dietary trans-FA and adenomas, this did not reach statistical significance.

Slattery et al. ${ }^{(34)}$ studied 1993 cases with colon cancer and 2410 population-based controls matched for age and sex. Dietary information was assessed from a detailed diet history questionnaire. A significant positive association was found between trans-FA consumption and colon cancer risk in women (OR 1.5), with a positive but not statistically significant association in men. Postmenopausal women who were not taking hormone replacement therapy had a twofold increase in risk from high levels of trans-FA in the diet, while the risk of developing colon cancer was unaffected by dietary trans-fat in women on hormone replacement therapy.

Nkondjock et al. ${ }^{(35)}$ compared the data from the dietary questionnaires of 402 cases of colorectal cancer with 668 population-based controls in Montreal, but found no effect of trans-FA in either men or women. A similar study involving 1455 cases and matched population-based controls in Scotland (UK) ${ }^{(36)}$ also observed no association between total trans-FA consumption and colorectal cancer after adjustment for intake of energy and total fatty acids.

\section{Prospective studies}

Lin et al. ${ }^{(37)}$ used dietary and health questionnaires from 37547 women in the Women's Health Survey to examine associations between diet and colorectal cancer. The authors found no statistically significant link between the consumption of trans-FA and colorectal cancer through their standard multivariate risk analysis, although the RR for trans-FA intake became stronger when adjusted for the consumption of other types of fat and cholesterol. There was a strong positive association between the intake of fried foods away from home and colorectal cancer risk (RR 1.86 $(95 \%$ CI 1.09, 3.16); $P$ for trend $=0.01)$.

\section{Summary of evidence for an association between trans-fatty acids and colorectal cancer}

One prospective cohort, one ecological and four casecontrol studies reported between 1997 and 2007 were reviewed. Apart from the ecological study, all studies used dietary assessment as the measure of exposure to trans-FA. Data from these case-control and prospective cohort studies are summarised in Fig. 2.

There are limited data available to assess evidence for an association between trans-FA intakes and incidence of colon cancer. Only one case-control study has shown a positive association, and this was significant only in women $^{(34)}$. In this study, the RR was 1.5 for a highest $v$. lowest quintile range of $<2.6$ to $>5.1 \mathrm{~g}$ trans-FA per d (based on an energy intake of $1700 \mathrm{kcal} / \mathrm{d}(7112 \mathrm{~kJ} / \mathrm{d})$ ), which is notably higher than the recent estimate of mean intake in the UK for women of $1.7 \mathrm{~g} / \mathrm{d}^{(3)}$.

Overall the epidemiological data are limited, with weak evidence to support an adverse effect of trans-FA intakes on colon cancer. The animal studies, which included very high

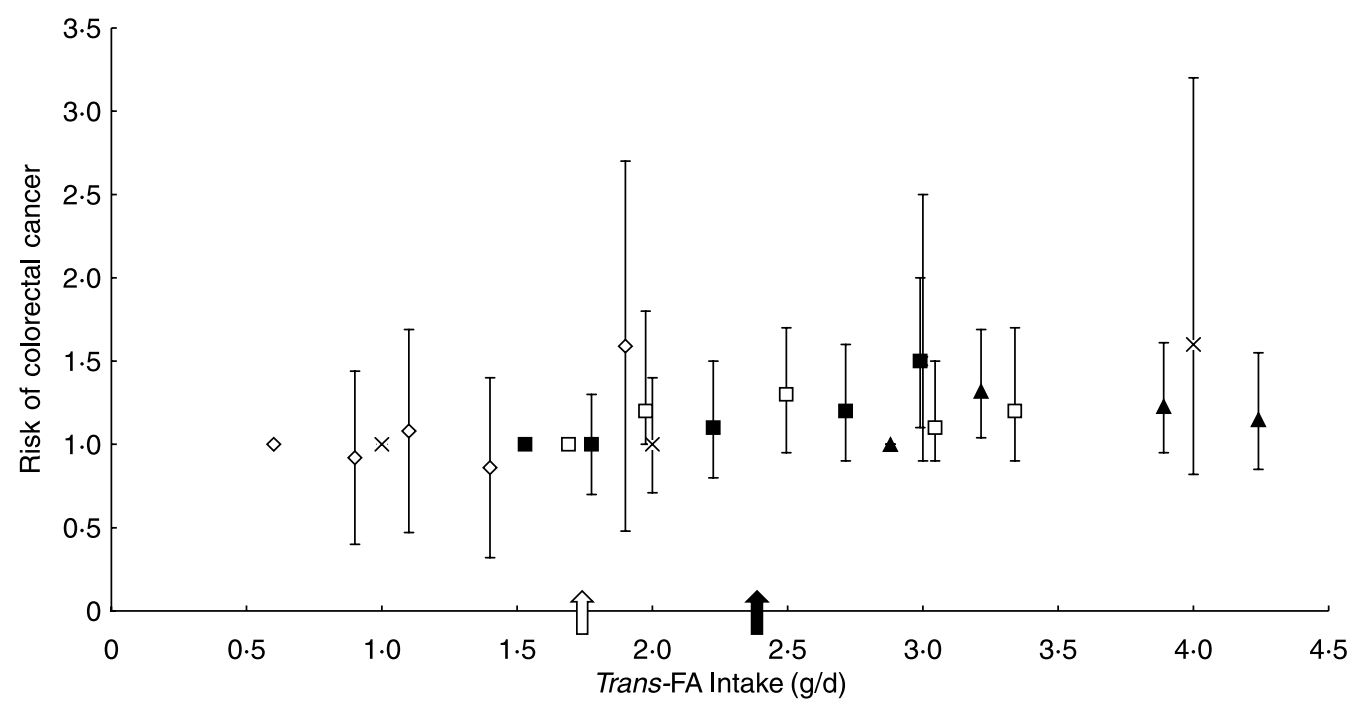

Fig. 2. Risk of colorectal cancer from case-control and prospective epidemiological studies that evaluated dietary intake of trans-fatty acids (trans-FA): McKelvey et al. ${ }^{(33)}(\times)$, Slattery et al. ${ }^{\left({ }^{34)}\right.}($ men $\square$; women $\mathbf{\square})$, Lin et al. ${ }^{(37)}(\diamond)$ and Theodoratou et al. ${ }^{\left({ }^{36)}\right.}(\mathbf{\Lambda})$. The current mean transFA intake in the UK has recently been estimated to be $1.0 \%$ of total energy or $1.7 \mathrm{~g} / \mathrm{d}$ for women ( $\hat{\imath}$ ) and $1.0 \%$ of total energy or $2.4 \mathrm{~g} / \mathrm{d}$ for men $(\uparrow)^{(3)}$. Risk of colorectal cancer is plotted as the relative risk (RR), with vertical bars representing the $95 \% \mathrm{Cl}$ for intake ranges above reference $(R R=1)$ in each study. Data from Lin et al. ${ }^{(37)}$ were converted from percentage of total energy to $\mathrm{g} / \mathrm{d}$ based on an energy intake of $1700 \mathrm{kcal} / \mathrm{d}$ $(7113 \mathrm{~kJ} / \mathrm{d})$ (study only included women). 
exposures to trans-FA, provided no evidence that trans-FA can enhance the development of colon tumours.

\section{Evidence for an association between trans-fatty acids and prostate cancer}

The methodology and findings for the studies examining the association between trans-FA and prostate cancer are summarised in Table 3.

\section{Ecological studies}

The ecological study by Bakker et al. ${ }^{(14)}$ examined the association between prostate cancer and trans-FA status measured in adipose tissue, but found no statistically significant correlation.

\section{Case-control studies}

Liu et al. ${ }^{(38)}$ assessed the potential modification of prostate cancer risk by a functional polymorphism in the RNASEL gene (R462Q). The study involved 1012 cases of prostate cancer and matched controls. Among Caucasians (n 834), a statistically significant positive association between prostate cancer and the intake of trans-FA (OR 2.77) was evident. The association remained strongly significant for all groups of trans isomers $(16: 1,18: 1$ and $18: 2$; all $P<0.005)$. There was no significant association in African American individuals. When the data for Caucasians were stratified by genotype, the association between total and isomer trans-FA intake and prostate cancer was strongest among men with the QQ/RQ genotype (OR 4.80). For men with the RR genotype, neither total trans-FA intake nor intake of any group of trans isomers was associated with prostate cancer.

\section{Prospective studies}

The Netherlands Cohort Study recruited 58279 men between 55 and 69 years of age, with an average followup of 6.3 years ${ }^{(39)}$. No association was found between total trans-FA consumption estimated through dietary questionnaires and development of prostate cancer.

Serum phospholipid trans-FA levels were compared in subjects that had been recruited for the $\beta$-Carotene and Retinol Efficacy Trial (CARET), a randomised trial of supplemental $\beta$-carotene and retinol for the prevention of lung cancer among 18314 heavy smokers and asbestosexposed workers $^{(40)}$. A sample of 272 men that developed prostate cancer and 426 matched controls showed increasing prostate cancer risk with higher levels of serum trans$18: 1 n-7$ (OR 1.69). Other trans-C18 fatty acids had positive trends with $P$ values of between 0.07 and $0 \cdot 12$, but none of the trans-C16 fatty acids were close to statistical significance.

Chavarro et al. ${ }^{(41)}$ analysed the trans-FA levels in whole blood from 476 men diagnosed with prostate cancer and controls matched according to age and smoking status at recruitment. The subjects were part of the Physicians' Health Study, a randomised trial of aspirin and $\beta$-carotene in which subjects received either the test compound or a placebo. There was no association between trans-FA levels and total prostate cancer risk, but stratification according to type of tumour showed significant correlations between total and isomer levels of trans-FA and non-aggressive tumours (OR 2.21). This association was stronger in overweight and obese men than in men with a normal BMI at baseline, and in men receiving placebo compared with men receiving aspirin. However, these interactions did not reach statistical significance. There was no association between trans-FA and aggressive prostate cancer for any trans-FA isomer or for any stratification of the cohort.

\section{Summary of evidence for an association between trans-fatty acids and prostate cancer}

One ecological, one case-control and three prospective studies were reviewed. Two of the prospective studies used serum phospholipids or whole-blood levels as the measure of exposure to trans-FA; the others used dietary assessment. Data from these case-control and prospective cohort studies that evaluated dietary trans-FA intake are summarised in Fig. 3.

There are very limited data available on which to base conclusions concerning possible adverse effects of trans-FA on prostate cancer. Two nested case-control studies have demonstrated a positive association between trans-FA intake and prostate cancer ${ }^{(40,41)}$, although in the most recent study this correlation was only for non-aggressive tumours. A large case-control study has observed a moderate increase in risk for the Caucasian population, but a very marked increase in risk for the RNASEL QQ/RQ genotype (about $35 \%$ of the population) ${ }^{(38)}$. The RNASEL gene is involved in protein coding and is a mediator of interferon action. Mutations in this gene have been associated with predisposition to prostate cancer, and the gene has been identified as a candidate for the hereditary prostate cancer 1 (HPC1) allele. The finding of an association between this gene, trans-FA and prostate cancer warrants further study.

\section{Evidence for an association between trans-fatty acids and other cancer types}

The methodology and findings for the studies examining the association between trans-FA and other types of cancer are summarised in Table 4.

\section{Non-Hodgkin's lymphoma}

It has been suggested that a higher intake of dietary fats could decrease immune response, leading to increased risk of developing non-Hodgkin's lymphoma (NHL). In the Nurses' Health Study, Zhang et al. ${ }^{(42)}$ examined the links between NHL and amount and composition of dietary fat. After 14 years of follow-up, a strong positive relationship was found between total trans-FA intake and an increased risk of NHL (RR 2.4). The statistically significant association between trans-FA consumption and development of NHL remained after further adjustments for other types of fat, protein, alcohol, and fruit and vegetable intake. The lowest to highest quintiles of trans-FA intake 
WS Nutrition Research Reviews

Table 3. Human studies investigating the association of trans-fatty acids (trans-FA) with prostate cancer

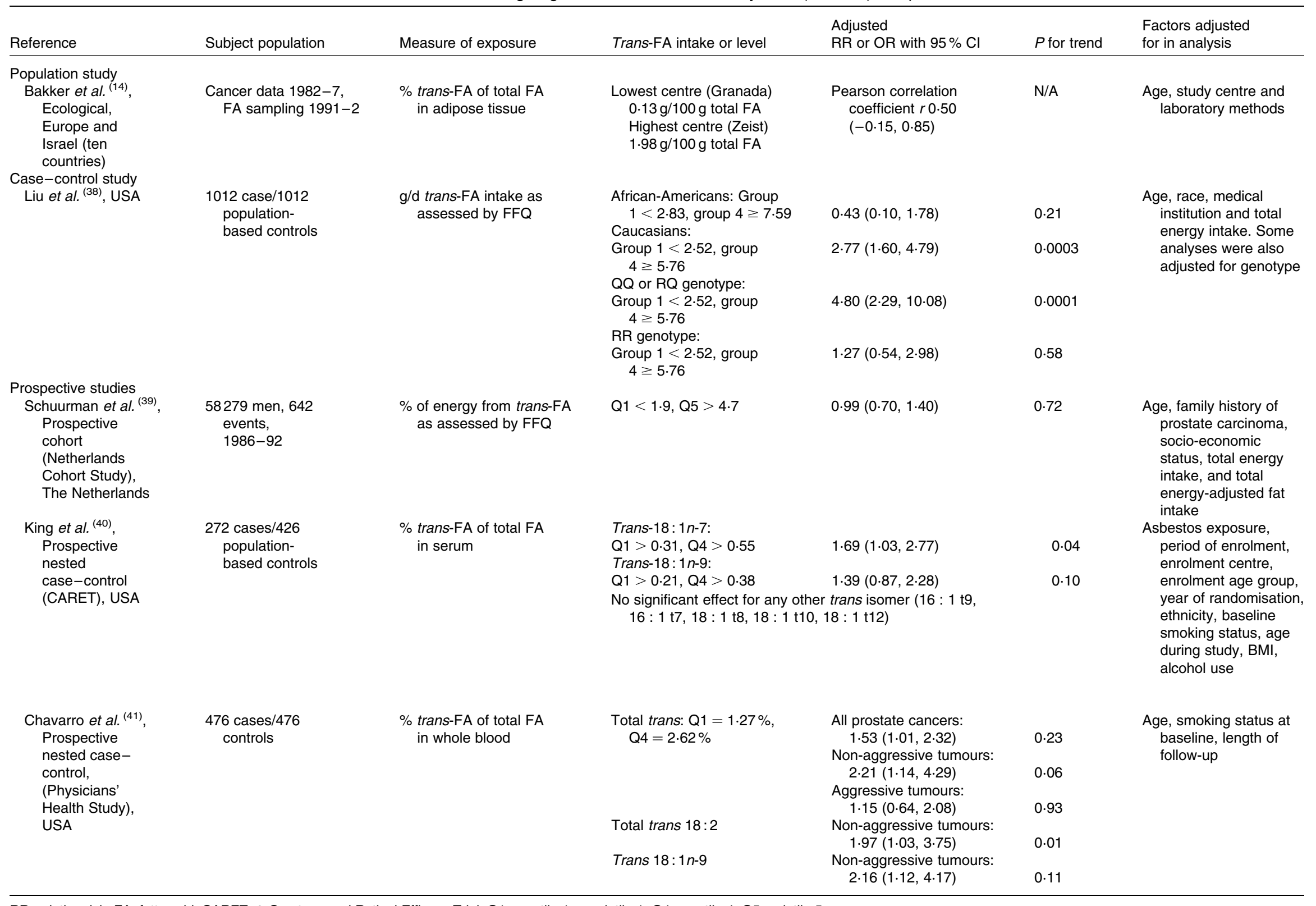

RR, relative risk; FA, fatty acid; CARET, $\beta$-Carotene and Retinol Efficacy Trial; Q1, quartile 1 or quintile 1; Q4, quartile 4; Q5, quintile 5. 
were $1.3-3.2 \mathrm{~g} / \mathrm{d}$, which are similar or slightly higher than the range of UK intakes ${ }^{(3)}$. The authors also considered the importance of the source of the trans-FA, and found that the link between NHL and trans-FA consumption was stronger for vegetable fat sources (RR 1.9) than animal fat sources (RR 1.4). However, it must be noted that this study based trans-FA intake on the dietary questionnaire completed in 1980, which is likely to introduce significant error due to the changes in food manufacturing and personal food choices over the course of the study.

\section{Ovarian cancer}

Data from the Nurses' Health Study were also used to assess the possible link between diet and risk of ovarian cancer ${ }^{(43)}$. In the 80258 pre- and postmenopausal women included in the analysis, 301 cases of ovarian cancer were diagnosed. There was no association between consumption of trans-FA and development of the disease.

\section{Pancreatic cancer}

Michaud et al. ${ }^{(44)}$ used the dietary and health data from the Nurses' Health Study to determine whether there was an association between diet and the risk of developing pancreatic cancer, but found no significant relationship.

\section{Summary of evidence for an association between trans-fatty acids and other forms of cancer}

There are limited data available to assess evidence for an association between trans-FA intakes and other forms of cancer. Data from the Nurses' Health Study provide preliminary evidence of a potential association between trans-fat consumption and NHL. However, further studies are required to enable the findings to be verified.

\section{Discussion}

Overall, there are few studies that have assessed the relationship between trans-FA intakes and cancer at specific sites. Many of the studies have been based in populations with intakes of trans-FA higher than those currently estimated for the UK. However, despite the higher intakes, the literature provides only limited evidence for a positive relationship between trans-FA consumption and cancer risk.

The cancer site for which most evidence is available on which to base a risk assessment is breast cancer, for which there are four case-control and ten prospective studies reported in the literature. Of the prospective studies, three are outputs from the original Nurses' Health Study, which has now reported follow-up of breast cancer over a period of 20 years with no evidence of an association with trans-FA intakes ${ }^{(19,20,22)}$. Three other prospective studies have reported a positive association ${ }^{(25,26,28)}$. Animal studies provide no evidence for an effect of trans-FA on mammary tumorigenesis. A plausible biological mechanism to explain any adverse effect of trans-FA on breast cancer is lacking.

Evidence for an association between trans-FA and cancers at other sites is sparse or limited and does not enable any meaningful risk assessment to be undertaken. However, the evidence for an association with particular types of prostate cancer ${ }^{(41)}$ or in individuals with specific genotypes $^{(38)}$ warrants further investigation. The strong association between NHL and trans-FA intakes reported from the Nurses' Health Study ${ }^{(43)}$ will require further verification by means of intake data based on more recent estimates of trans-FA in this study population.

A statistically significant association was reported for vegetable oil trans-FA but not animal trans-FA and $\mathrm{NHL}^{(43)}$. One prospective study on breast cancer ${ }^{(26)}$ and a prospective study on prostate cancer ${ }^{(40)}$ reported a positive association that was strongest for trans-18:1n-7. However, the presence

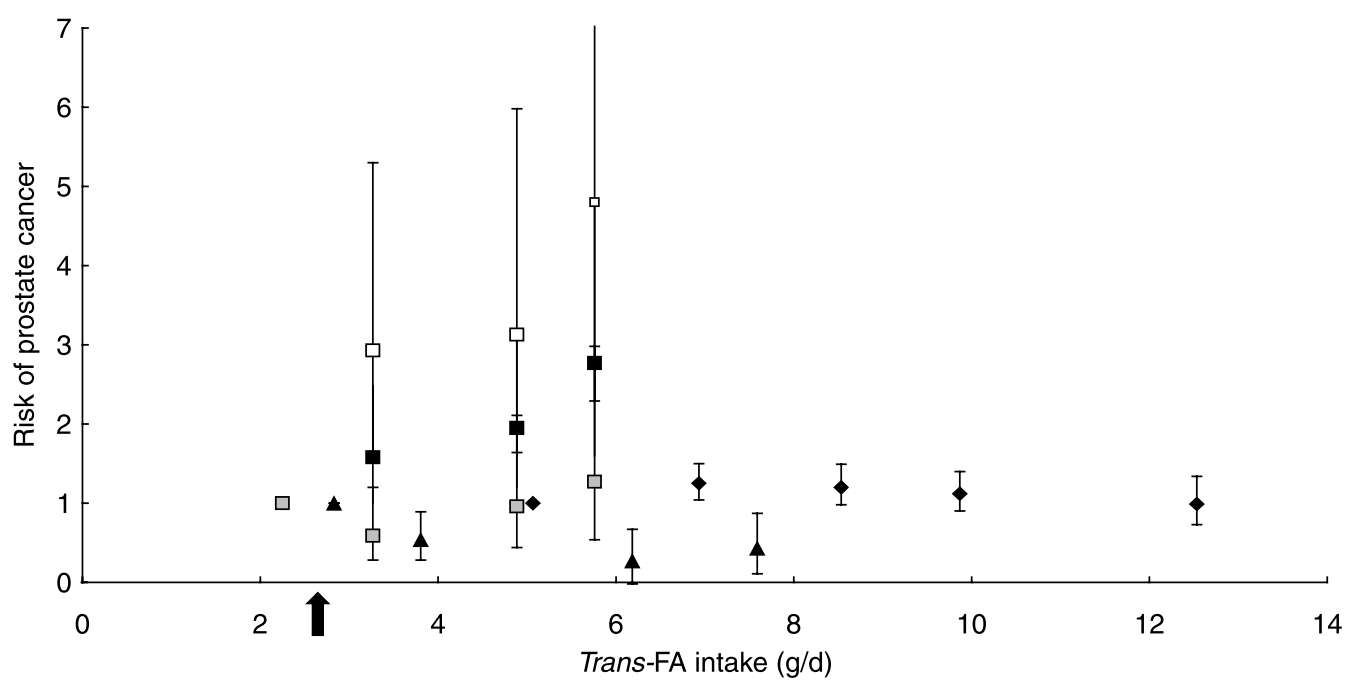

Fig. 3. Risk of prostate cancer from case-control and prospective epidemiological studies that evaluated dietary intake of trans-fatty acids (transFA): Schuurman et al. ${ }^{(39)}$ (all men $\diamond$ ) and Liu et al. ${ }^{(38)}$ (African-American $\mathbf{\Delta}$; Caucasian $\mathbf{\square}$; Caucasian $Q$ allele $\square$; Caucasian no Q allele $\square$ ). The current mean trans-FA intake in the UK for men has recently been estimated to be $1.0 \%$ of total energy or $2.4 \mathrm{~g} / \mathrm{d}(\uparrow)^{(3)}$. Risk of prostate cancer is plotted as the relative risk (RR), with vertical bars representing the $95 \% \mathrm{Cl}$ for intake ranges above reference (RR 1) in each study. Data from Schuurman et al. ${ }^{(39)}$ were converted from percentage of total energy to $\mathrm{g} / \mathrm{d}$ based on an energy intake of $2400 \mathrm{kcal} / \mathrm{d}(10042 \mathrm{~kJ} / \mathrm{d})$. Reference points for Caucasians and genotypes from Liu et al. ${ }^{(38)}$ are all at $2 \cdot 25 \mathrm{~g} / \mathrm{d}$. 
of trans-18: $1 n-7$ in both vegetable oil and animal products prevents these data from providing clear conclusions on the effects of the different sources.

\section{Future work}

There is a lack of consistent evidence for an association between trans-FA intake and either breast or colon cancers from human studies, and published outcomes from animal studies have yet to provide a plausible mechanism for such a relationship. Consideration should be given to the possibility that, if the impact of trans-FA intake on risk is small or moderate, then measurement error ${ }^{(7,8)}$, in dietary assessment and/or biomarker fatty acid analyses, may have reduced the possibility of obtaining positive findings. Measurement error in dietary assessment can be reduced though use of multiple methods of assessment (diet records, food frequency, questionnaires, $24 \mathrm{~h}$ recalls) and through repeat measurement during the period of follow-up. Repeat measurement is of particular importance in the case of trans-FA, because intakes may have changed considerably over time due to changes in food manufacturing processes. These ideal conditions apply to only a few studies included within the present review. Further prospective studies are needed in which repeat measurements, using more than one assessment method, are made throughout the period of follow-up. Data from the EPIC study, which has applied these criteria in the dietary assessment protocols and which includes populations with a wide range of trans-FA intakes, would be of particular value.

Despite the small number of studies, the data reviewed here suggest that the evidence for a link between trans-FA and prostate cancer appears to be growing. However, it is critical that assumptions regarding this potential association are not made without sufficient basis. The current information appears sufficient to justify initiating prospective studies that are well designed and to consider the possibility of a genotype interaction. Additional investigation into possible mechanisms would also be worthwhile; although there is little basis for such studies at present, possible hormonal effects of trans-FA should be considered given the existing evidence for a possible protective antioestrogen-like action for CLA.

The single study looking at trans-FA and NHL raises the possibility of an association, but this is an inadequate basis upon which to advise further new investigations. Existing cohorts that have information on trans-FA intake or tissue levels and the potential to access information on NHL cases are encouraged to conduct the appropriate statistical analysis and publish their findings in order to help clarify whether this is a real association.

Further animal studies would appear to be of limited value, since outcomes from the very large number of studies conducted to assess relationship between fat or specific fatty acid intakes and cancer appear to have little relevance to human diet exposures and risk of cancer.

\section{Conclusion}

There is weak and inconsistent evidence for a relationship between trans-FA and breast or colorectal cancer. Evidence 
for an association between trans-FA and prostate cancer is limited, but there are two prospective studies that report positive correlations, and a recent large case-control study has shown a strong interaction between risk and trans-FA intake for a particular genotype that makes up about $35 \%$ of the population. This potential association requires further investigation. Use of an existing cohort that includes rigorous dietary assessment and tissue sampling for biomarker fatty acid measurement (such as EPIC) would appear to be strongly justified. The strong association between NHL and trans-FA intakes reported in a single study require further verification by means of intake data based on more recent estimates of trans-FA intake. There is inadequate information in order to distinguish between the effects of trans-FA of animal or vegetable origin on the risk of cancer.

\section{Acknowledgements}

There are no conflicts of interest.

\section{References}

1. McGovern G (1977) Dietary Goals for the United States; Report of the Select Committee on Nutrition and Human Needs, US Senate. Cambridge, MA: MIT Press.

2. Eniq M, Munn R \& Keeney M (1978) Dietary fat and cancer trends - a critique. Fed Proc 37, 2215-2220.

3. Williams C, Thompson A, Shaw D, et al (2007) Update on Trans-Fatty Acids and Health. Position Statement by the Scientific Advisory Committee on Nutrition. London: The Stationery Office.

4. Henderson L, Gregory J, Irving K, et al (2003) The National Diet and Nutrition Survey: Adults Aged 19-64 Years, vol. 2. London: HM Stationery Office.

5. Food and Drug Administration \& HHS (2003) Food labeling: trans fatty acids in nutrition labeling, nutrient content claims, and health claims. Final rule. Fed Reg 68, 41433-41506.

6. Hulshof K, van Erp-Baart M, Anttolainen M, et al. (1999) Intake of fatty acids in Western Europe with emphasis on trans fatty acids: the TRANSFAIR study. Eur J Clin Nutr 53, $143-157$.

7. Margetts BM \& Nelson M (1997) Design Concepts in Nutritional Epidemiology, 2nd ed. Oxford: Oxford University Press.

8. Department of Health (1998) Nutritional Aspects of the Development of Cancer. London: The Stationery Office.

9. Selenskas SL, Ip MM \& Ip C (1984) Similarity between trans fat and saturated fat in the modification of rat mammary carcinogenesis. Cancer Res 44, 1321-1326.

10. Erickson KL, Schlanger DS, Adams DA, et al. (1984) Influence of dietary fatty acid concentration and geometric configuration on murine mammary tumorigenesis and experimental metastasis. $J$ Nutr 114, 1834-1842.

11. Lock AL, Corl BA, Barbano DM, et al. (2004) The anticarcinogenic effect of trans-11 181 is dependent on its conversion to cis-9, trans-11 CLA by $\Delta 9$-desaturase in rats. J Nutr 134, 2698-2704.

12. Santora JE, Palmquist DL \& Roehrig KL (2000) Transvaccenic acid is desaturated to conjugated linoleic acid in mice. J Nutr 130, 208-215

13. Turpeinen AM, Mutanen M, Aro A, et al. (2002) Bioconversion of vaccenic acid to conjugated linoleic acid in humans. Am J Clin Nutr 76, 504-510.
14. Bakker N, van't Veer P, Zock PL, et al. (1997) Adipose fatty acids and cancers of the breast, prostate and colon: an ecological study. Int J Cancer 72, 387-391.

15. London SJ, Sacks FM, Stampfer MJ, et al. (1993) Fatty acid composition of the subcutaneous adipose tissue and risk of proliferative benign breast disease and breast cancer. $J$ Natl Cancer Inst 85, 785-793.

16. Petrek JA, Hudgins LC, Levine B, et al. (1994) Breast cancer risk and fatty acids in the breast and abdominal adipose tissues. J Natl Cancer Inst 86, 53-56.

17. Kohlmeier L, Simonsen N, van 't Veer P, et al. (1997) Adipose tissue trans fatty acids and breast cancer in the European Community Multicenter Study on Antioxidants, Myocardial Infarction, and Breast Cancer. Cancer Epidemiol Biomarkers Prev 6, 705-710.

18. Aro A, Männistö S, Salminen I, et al. (2000) Inverse association between dietary and serum conjugated linoleic acid and risk of breast cancer in postmenopausal women. Nutr Cancer 38, 151-157.

19. Holmes MD, Hunter DJ, Colditz GA, et al. (1999) Association of dietary intake of fat and fatty acids with risk of breast cancer. JAMA 281, 914-920.

20. Byrne C, Rockett H \& Holmes MD (2002) Dietary fat, fat subtypes, and breast cancer risk: lack of an association among postmenopausal women with no history of benign breast disease. Cancer Epidemiol Biomarkers Prev 11, $261-265$.

21. Cho E, Spiegelman D, Hunter DJ, et al. (2003) Premenopausal fat intake and risk of breast cancer. J Natl Cancer Inst 95, 1079-1085.

22. Kim EHJ, Willett WC, Colditz GA, et al. (2006) Dietary fat and risk of postmenopausal breast cancer in a 20-year followup. Am J Epidemiol 164, 990-997.

23. Pala V, Krogh V, Muti P, et al. (2001) Erythrocyte membrane fatty acids and subsequent breast cancer: a prospective Italian study. J Natl Cancer Inst 93, 1088-1095.

24. Saadatian-Elahi M, Toniolo P, Ferrari P, et al. (2002) Serum fatty acids and risk of breast cancer in a nested case-control study of the New York University Women's Health Study. Cancer Epidemiol Biomarkers Prev 11, 1353-1360.

25. Voorrips LE, Brants HAM, Kardinaal AFM, et al. (2002) Intake of conjugated linoleic acid, fat, and other fatty acids in relation to postmenopausal breast cancer: the Netherlands Cohort Study on Diet and Cancer. Am J Clin Nutr 76, $873-882$.

26. Rissanen H, Knekt P, Jarvinen R, et al. (2003) Serum fatty acids and breast cancer incidence. Nutr Cancer 45, 168-175.

27. Shannon J, King IB, Moshofsky R, et al. (2007) Erythrocyte fatty acids and breast cancer risk: a case-control study in Shanghai. China. Am J Clin Nutr 85, 1090-1097.

28. Chajes V, Thiebaut ACM, Rotival M, et al. (2008) Association between serum trans-monounsaturated fatty acids and breast cancer risk in the E3N-EPIC Study. Am J Epidemiol 167, 1312-1320.

29. Watanabe M \& Koga T (1985) Sugano M Influence of dietary cis- and trans-fat on 1,2-dimethylhydrazine-induced colon tumors and fecal steroid excretion in Fischer 344 rats. Am J Clin Nutr 42, 475-484.

30. Sugano M, Watanabe M, Yoshida K, et al. (1989) Influence of dietary cis and trans fats on DMH-induced colon tumors, steroid excretion, and eicosanoid production in rats prone to colon cancer. Nutr Cancer 12, 177-187.

31. Hogan ML \& Shamsuddin AM (1984) Large intestinal carcinogenesis. I. Promotional effect of dietary fatty acid isomers in the rat model. J Natl Cancer Inst 73, 1293-1296.

32. Reddy BS \& Tanaka T (1985) Simi B Effect of different levels of dietary trans fat or corn oil on azoxymethane-induced 
colon carcinogenesis in F344 rats. J Natl Cancer Inst 75, 791-798.

33. McKelvey W, Greenland S, Chen M-J, et al. (1999) A casecontrol study of colorectal adenomatous polyps and consumption of foods containing partially hydrogenated oils. Cancer Epidemiol Biomarkers Prev 8, 519-524.

34. Slattery ML, Benson J, Ma K-N, et al. (2001) Trans-fatty acids and colon cancer. Nutr Cancer 39, 170-175.

35. Nkondjock A, Shatenstein B, Maisonneuve P, et al. (2003) Assessment of risk associated with specific fatty acids and colorectal cancer among French-Canadians in Montreal: a case-control study. Int J Epidemiol 32, 200-209.

36. Theodoratou E, McNeill G, Cetnarskyj R, et al. (2007) Dietary fatty acids and colorectal cancer: a case-control study. Am J Epidemiol 166, 181-195.

37. Lin J, Zhang SM, Cook NR, et al. (2004) Dietary fat and fatty acids and risk of colorectal cancer in women. Am J Clin Nutr 160, 1011-1022.

38. Liu X, Schumacher FR, Plummer SJ, et al. (2007) Trans-fatty acid intake and increased risk of advanced prostate cancer: modification by RNASEL R462Q variant. Carcinogenesis 28, $1232-1236$.
39. Schuurman AG, van den Brandt PA, Dorant E, et al. (1999) Association of energy and fat intake with prostate carcinoma risk: results from the Netherlands Cohort Study. Cancer 86, 1019-1027.

40. King IB, Kristal AR, Schaffer S, et al. (2005) Serum transfatty acids are associated with risk of prostate cancer in betacarotene and retinol efficacy trial. Cancer Epidemiol Biomarkers Prev 14, 988-992.

41. Chavarro JE, Stampfer MJ, Campos H, et al. (2008) A prospective study of trans-fatty acid levels in blood and risk of prostate cancer. Cancer Epidemiol Biomarkers Prev 17, 95-101.

42. Zhang S, Hunter DJ, Rosner BA, et al. (1999) Dietary fat and protein in relation to risk of non-Hodgkin's lymphoma among women. $J$ Natl Cancer Inst 91, 1751-1758.

43. Bertone ER, Rosner BA, Hunter DJ, et al. (2002) Dietary fat intake and ovarian cancer in a cohort of US women. Am J Epidemiol 156, 22-31.

44. Michaud DS, Giovannucci E, Willett WC, et al. (2003) Dietary meat, dairy products, fat, and cholesterol and pancreatic cancer risk in a prospective study. Am J Epidemiol 157, 1115-1125. 